\title{
RETRACTION NOTE TO: THE IMPACT OF SOCIAL ADVERTISING \\ CAMPAIGNS IN SHAPING EGYPTIAN YOUTH'S BEHAVIORAL INTENTIONS
}

\author{
Alaa El-Gharbawy
}

\begin{abstract}
Retraction Note to:
Chapter 47 in: Robinson, Jr. L. (eds) Marketing Dynamism \& Sustainability: Things Change, Things Stay the Same.... Developments in Marketing Science: Proceedings of the Academy of Marketing Science. Springer, Cham. https://doi.org/10.1007/978-3-319-10912-1_47
\end{abstract}

The Editors have retracted this chapter [1] because it shows significant overlap with a previously published article [2]. The author has not responded to any correspondence from the Editors about this retraction.

[1] El-Gharbawy A. (2015) The Impact of Social Advertising Campaigns in Shaping Egyptian Youth's Behavioral Intentions. In: Robinson, Jr. L. (eds) Marketing Dynamism \& Sustainability: Things Change, Things Stay the Same.... Developments in Marketing Science: Proceedings of the Academy of Marketing Science. Springer, Cham

[2] Sahar Mohamed Rafaat Abu Gharara, Mohamed Farid El Sahn and Dalia Abdel Rahman Farrag (2013) Measuring the effectiveness of social advertising campaigns in shaping youths' behavioral intentions, with the moderating role of advertising scepticism. The Macrotheme Review 2 (7), Winter 2013

The retracted version of this chapter can be found at https://doi.org/10.1007/978-3-319-10912-1_47

(C) Academy of Marketing Science 2021

Robinson, Jr. L. (eds) Marketing Dynamism \& Sustainability: Things Change, Things Stay the Same.... Developments in Marketing Science:

Proceedings of the Academy of Marketing Science. Springer, Cham. https://doi.org/10.1007/978-3-319-10912-1_260 